\title{
Urgences
}

\section{Le grenier}

\section{Michelle Dubois}

Numéro 14, août 1986

Corps et jouissances

URI : https://id.erudit.org/iderudit/025262ar

DOI : https://doi.org/10.7202/025262ar

Aller au sommaire du numéro

Éditeur(s)

Urgences

ISSN

0226-9554 (imprimé)

1927-3924 (numérique)

Découvrir la revue

Citer ce document

Dubois, M. (1986). Le grenier. Urgences, (14), 37-43.

https://doi.org/10.7202/025262ar

Ce document est protégé par la loi sur le droit d'auteur. L'utilisation des services d'Érudit (y compris la reproduction) est assujettie à sa politique d'utilisation que vous pouvez consulter en ligne.

https://apropos.erudit.org/fr/usagers/politique-dutilisation/ 
Michelle Dubois

\section{LE GRENIER}


je cherche ma voix dans l'escalier au plus haut la tête courbée sous la trappe close je cherche penchée sur des signes de papier labyrinthe le parcours difficile déjà franchi le silence inscrit noir le mouvement des lèvres l'issue trompe-l'oeil sur la caverne j'entends en toutes lettres l'affolant désir du sens j'avale la piste les repères j'absorbe l'élan je bois plein de signaux de cataclysmes péril perché le serpent glisse sous la trappe du grenier 
le bel étage où je franchis les murs l'émoi dans le bois brut le bruit des pluies les soies passées je m'invente je tisse des peaux de nonne des pleurs des péchés je brode du temps sur mes yeux recluse si haut ici je m'étire de toutes mes images je me regarde nue drapée dans la frayeur unique du regard 
il fait chaud le toit ondule je respire un peu la lumière dans le papier jauni le sceau fragile de l'encre je lis l'avant-hier recueilli les piles de passé fontaine drue fraîcheur je bois cette histoire la vérité ma mère le cinéma à portée de bouche le vin la réserve rouge dans la mémoire des araignées fileuses je recueille le sang goutte à goutte je me cueille 
si près de la pluie sous le toit les bardeaux me touchent j'insiste à petits coups je m'étends sous la cadence je colle mon coeur la langue des pluies me lèche là je soupire des deux mains j'ouvre ce qu'il faut j'entrouve pour les yeux la pluie me veut le mords au ventre je guide la persistance des flèches les nuages roulent bas j'ondule vers l'orage j'endosse la frange muette l'étage blanc le lendemain 
je souffle dans la fenêtre je cherche le vent dans la vitre des arbres sombres la dureté des traits noirs des ombres de corbeaux nichés tromperie du poing je brise la transparence éclate mille cris de perte j'ouvre les doigts aiguilles je brode des yeux des mains le paysage l'image je veux des mains sur mes désirs des plaintes je fabrique mes allées complices la tragédie éclatera dans mes mots j'écris 
je dors ici parfois je m'en viens seule dans la bouche des chuchotements je déroule ma voix jusqu'aux poutres dans l'angle le ventre habité j'écoute mon éclatement tendre pour la nuit je fleuris noir j'habite tout le creux entre les mains les fenêtres j'ouvre mon plaisir mes yeux mes lèvres multiples les murmures fouillent l'épaisseur la distance je me veux 